\title{
Onion (Allium cepa) and garlic (Allium sativum) as pest control intercrops in cabbage based intercrop systems in Zimbabwe
}

\author{
Katsaruware Rumbidzai Debra ${ }^{1}$, Dubiwa Misheck ${ }^{2}$ \\ ${ }^{I}$ Department of Agricultural Management; Zimbabwe Open University, Mashonaland West Regional \\ Campus,Zimbabwe. \\ ${ }^{2}$ Karoi Government High School, Zimbabwe.
}

\begin{abstract}
Cultural methods can be implemented to reduce the problems that have been caused by indiscriminate use of insecticides. An experiment was carried out in Makonde District, Zimbabwe to determine the ability of onion and garlic to reduce pest problem when intercropped with cabbages. A randomised complete block design was used with five treatments replicated three times. The treatments were (1) cabbage intercropped with garlic within rows, (2) cabbage intercropped with onion within rows (3) Cabbage and onion intercropped within rows (4) Cabbage and garlic intercropped within rows and (5) Sole cabbage. Data collected were on pest prevalence at physiological maturity, cabbage plants that survived at three weeks after planting (WAP), number of cabbage leaves damaged by insect pests at 6 (WAP), cabbage head diameter and yield of cabbages at physiological maturity. Intercropping cabbage significantly reduced pest prevalence, plant death after transplanting, leaf damage and increased cabbage yield compared to sole cabbage crop. However there were generally more benefits when intercropping with either garlic or onions between the rows than within the rows though not statistically different from intercropping within the cabbage rows at $p<0.05$.
\end{abstract}

Keywords: Allium cepa, Allium sativum, cabbage, intercrop, pest control.

\section{Introduction}

Cabbage (Brassicae oleracea) is an important leafy vegetable in both small and large scale sectors in most African countries [1]. The significance of cabbage lies in its high nutritive value [2], variety of dishes that can be prepared from it as well as the creation of employment through the labour required for producing the crop [3]. The high nutritive value of cabbages in the form of protein, vitamin, calcium, iron and carotene makes it susceptible to insect pest attack [4].The pests that attack cabbages include aphids (Aphis brassicae), diamondback moth (Plutella xylostella), the cabbage webworm (Hellula undalis), the cabbage looper, (Trichoplusia) [5]. Plant pests cause considerable damages and losses in vegetable production. Some of the pests suck cell sap from plants which reduces plant potential to photosynthesise, destroy growing buds as well as tunnelling into whole cabbage heads [6]. This reduces plant productivity and decline in market value of the produce as a result of tear and shattering [7] and subsequent loss to the farmer [6], in some cases total crop failure [5].

Despite the efficiency, and ease of utilisation, synthetic pesticides result in environmental contamination and water pollution (when toxic substances introduced into water bodies in quantities which affect the resource in providing valuable services of domestic use, navigation, irrigation, recreational and life (ecological) functions [6]. The European Union (E U) has put in place some restrictive compliance standards, one of which pertains to chemical residues in food produce [8]. In some studies, [5] evaluated botanicals that significantly reduced pest populations and conveniently maintained the ecological balance with their natural enemies on okra and eggplants.

Crop species grown together in an intercrop system interact and influence each other. These relationships can be beneficial or detrimental [10]. Intercropping takes an advantage of the benefits of growing plants together. Combining the right vegetable crops and herbs can reduce the need for chemical pesticides in the garden by repelling insects and limiting the spread of diseases [10]. The benefits of intercropping include better use of growing area, increased insect pest and disease resistance, increased predator insect populations, increased weed suppression, trap cropping for pest control, nurse cropping which means one crop sacrificing for another and better long term soil use. Intercropped plants grow to their maximum potential, live and grow in a minimum of stress and provide the healthiest crop. Unstressed plants are therefore more able to resist insect attack [11].

Herbs such as onion (Allium cepa) and garlic (Allium sativum) have been used in the intercropping systems because of their ability to repel insects. Cole crops grown next to garlic and onion are less prone to insect pest attacks. Onion and garlic plants produce excretions from their roots as well as aromas from their leaves. These excretions and aromas have beneficial effects on surrounding plants. They will discourage insects, and are therefore regarded as insect repellent plants [11]. Natural pesticides are safer and eco-friendly. They 
reduce artificial interference and cut down on the use of synthetic pesticides [12]. In addition, they reduce cost of health management on farms because they reduce inhalation of toxic fumes of synthetic chemicals. Garlic (Allium sativum) and onion (Allium cepa) is widely grown and is easy to cultivate in gardens. Garlic in particular, is reportedly effective against a wide range of disease-causing pathogens and insect pests at different stages in their life cycles. Allicin is a compound obtained from garlic [13]. The compound is a colourless liquid which has a distinctively pungent smell which reveals anti-bacterial and anti-fungal properties. Allicin in garlic imparts defence mechanism against attacks by insect pests [13].

\subsection{Description of the study area}

\section{Materials And Methods}

The study was done in Ward Eighteen of Hurungwe District in the Mashonaland West province. The study area falls under the natural ecological zone $2 \mathrm{~b}$ characterized by intensive farming based on livestock rearing and crop production. The annual rainfall ranges between $700 \mathrm{~mm}-1050 \mathrm{~mm}$ with $16-18$ pentads per season. Temperature ranges between $20-30^{\circ} \mathrm{C}$ during summer and $5-19^{\circ} \mathrm{C}$ during winter. The soil types range from light sands to sandy loam. The topography of the study area is generally gentle slope.

\subsection{Treatment Description and Experimental Design}

There were five treatments and three replicates, giving a total of fifteen experimental plots. The Randomized Complete Block Design was used because it allowed for the replication and randomization of treatments. Each of the 15 plots measured $5 \mathrm{~m} \times 2 \mathrm{~m}$ were used the experiment. The treatments were: (1) cabbage intercropped with garlic within rows, (2) cabbage intercropped with onion within rows (3) Cabbage and onion intercropped within rows (4) Cabbage and garlic intercropped within rows and (5) Sole cabbage.

\subsection{Field Preparation}

An ox-drawn plough was used for the primary tillage operation. A spike-toothed harrow was used on the same date to break soil clods and make a fine seed bed. The primary and second tillage operations on the field were meant to destroy existing plants and weeds, improve soil aeration so as to encourage microbial activity and improve water infiltration. Fifteen equal plots of $10 \mathrm{~m}^{2}$ area each replicated three times were marked and constructed. Planting rows and stations were marked as per specification on the fifteen plots.

\subsection{Crop Management}

The fifteen experimental plots were watered twice per week using a watering can with a fine rose fine rose the first 2 weeks after planting (WAP). Soil moisture content was maintained at levels that promoted plant growth. A basal dressing of compound $\mathrm{D}\left(\mathrm{N}_{8}, \mathrm{P}_{14}, \mathrm{~K}_{7}\right)$ fertilizer was applied at a rate of $30 \mathrm{~g} \mathrm{~m}^{-2}$. The basal fertilizer was broadcasted at that time of seedbed preparation, two weeks before the seedlings were transplanted. Top dressing fertilizer (Ammonium Nitrate for the cabbage and Double Super Phosphate for garlic and onion) was applied at four week stage of plant growth from the date of transplanting. Hill placement method was used for the application of Ammonium Nitrate.

\subsection{Data collection}

The following parameters were measured: Pest prevalent at maturity, total number of cabbage plants that survived at 3WAP, percentage number of cabbage leaves damaged by insect pests at 6 (WAP), cabbage head diameter and yield at physiological maturity.

\subsection{Data analysis}

Data collected was analysed using the computer package Genstat to test the differences in means. Mean separation was done using Least Significant Differences (LSD) at $\mathrm{p}<0.05$.

\section{Results}

Table 1: Pest prevalent at $12 \mathrm{WAP}$, plants surviving at $3 \mathrm{WAP}$, number of leaves damaged at $6 \mathrm{WAP}$, cabbage diameter at physiological maturity and yield of cabbages at physiological maturity

\begin{tabular}{|l|l|l|l|l|l|}
\hline Treatment & PP & PS & LD & CD & YPM \\
\hline 1. Cabbage and garlic intercrops within cabbage rows. & $2.87 \mathrm{c}$ & $88.9 \mathrm{~b}$ & $2.67 \mathrm{~b}$ & $16.6 \mathrm{a}$ & $22.4 \mathrm{~b}$ \\
\hline 2. Cabbage and onion intercrops within cabbage rows & $2.73 \mathrm{c}$ & $91.7 \mathrm{~b}$ & $3.67 \mathrm{~b}$ & $16.6 \mathrm{a}$ & $22.4 \mathrm{~b}$ \\
\hline 3. Cabbage and onion intercrops between cabbage rows & $0.333 \mathrm{~b}$ & $100 \mathrm{~b}$ & $0.00 \mathrm{a}$ & $16.7 \mathrm{a}$ & $22.4 \mathrm{~b}$ \\
\hline 4. Cabbage and garlic intercrops between cabbage rows & $0.00 \mathrm{a}$ & $100 \mathrm{~b}$ & $0.00 \mathrm{a}$ & $16.7 \mathrm{a}$ & $22.4 \mathrm{~b}$ \\
\hline 5. Sole cabbage & $7.73 \mathrm{~d}$ & $77.8 \mathrm{a}$ & $13.0 \mathrm{c}$ & $15.6 \mathrm{a}$ & $17.8 \mathrm{a}$ \\
\hline S e d & 0.321 & 3.922 & 0.596 & 0.843 & 1.520 \\
\hline
\end{tabular}


Onion (Allium cepa) and garlic (Allium sativum) as pest control intercrops in cabbage based

\begin{tabular}{|l|l|l|l|l|l|}
\hline $\mathrm{LSD}_{0.05}$ & 0.6885 & 8.412 & 1.279 & 1.809 & 3.260 \\
\hline
\end{tabular}

Means followed by different letters within the same column are statistically different at $(\mathbf{P}<0.05)$ *Significance at $\alpha=0.05$, NS-Not Significant

PP (Pest prevalent at 12 WAP), PS (Plants surviving at $3 \mathrm{WAP}$ ), LD (number of leaves damaged at 6WAP), CD

(Cabbage diameter at physiological maturity, YPM (Yield at physiological maturity).

\subsection{Pest prevalence at 12 WAP}

Results of the study shows that there was no significant difference on the prevalence of pests between cabbage-garlic within rows (2.87) and cabbage-onion within rows (2.73) intercrops. These intercrops had significantly different pest prevalence from sole cabbage as well as the other intercrops with either onion or garlic between the cabbage rows. No pests were found in cabbage intercrop with onion in the interrows (between rows). The highest (7.73) pest prevalent was observed in sole cabbage (Table 1).

\subsection{Percentage of cabbage plants surviving in the first 3 WAP}

The study reveals that there were significant differences in the percentage of plants surviving at 3 Weeks after planting (WAP) between sole cabbage and all the other intercrops. Sole cabbage had the lowest percentage of plant survival (77.8\%) while the intercrop containing either garlic or cabbage in the inter row achieved $100 \%$ plant survival. Although the highest was $100 \%$ they were however not significantly different from the other intercrops where either garlic or onion were planted within the rows with $88.9 \%$ and $91.7 \%$ respectively (Table 1).

\subsection{Cabbage leaves damaged by insect pests at week 6 WAP}

The number of damaged leaves at 6 WAP was highest in the sole cabbage treatment (13.0) while the lowest were in the intercrops with either onion or garlic between the rows which both had 0 leaves damaged. In cabbage intercropped with garlic within rows and cabbage and onions within rows the numbers of damaged leaves were 2.67 and 3.67 respectively which were not statistically significant $(\mathrm{p}<0.05)$ from the other intercrops.

\subsection{Cabbage diameter at physiological maturity}

The lowest cabbage diameter was at $15.6 \mathrm{~cm}$ in sole cabbage that was not significantly different from all the other intercropping treatments. In intercrops having garlic or onions between rows, both treatments had diameters of $16.7 \mathrm{~cm}$ while for the intercrops where garlic or onion where planted within rows, the diameters for the cabbages were also 16.6 for both treatments. However, there was no significant difference in the diameter of cabbage plants between all the intercrops and sole cabbages.

\subsection{Cabbage yield at physiological maturity}

At physiological maturity, harvested marketable yield was lowest $(17.8 \mathrm{~kg})$ in sole cabbage treatment while in all the other intercrops it was higher at $22.4 \mathrm{~kg}$ per plot (Table 1). In all the intercrops, there was no significant difference in the yield of marketable cabbages as all the cabbages attained a yield of $22.4 \mathrm{~kg}$.

\section{Discussion
4.1Pest prevalence on cabbage plants at physiological maturity}

Pest prevalence was lower in intercropping treatments due to fewer Bemisia tabaci, Hellula undalis and Brevicoryne brassicae [6] that infested the intercropped plants than the sole crop. Garlic and onion are potentially effective in controlling pests on cabbages. Onion and garlic produced compounds such as allicin that had repellent effects on insect pests on treatments 1,2,3, and 4. The allicin compounds repelled insect pests [13] while in sole cabbage there was no any allicin to repel the insect pests therefore resulting in a higher pest incidence in the sole treatment. In another study in Kenya it was also observed that intercropped cabbage or kale had significantly fewer numbers of Diamond Back Moth (DBM) larvae and pupae as compared to the monocrops of either kale or cabbage plots [14].

\subsection{Plants survival on treatments at 3 WAP.}

There was a higher number of plants that have survived in the intercropping system possibly due to a reduction in attack on the cabbages that were intercropped with either onion or garlic. The pests which killed the cabbage plants that were observed were mainly the cutworms. No pests were evident in cropping systems where onion and garlic were included. This proves the research done by [15] which showed that onion and garlic produced alkaloids and glycosides which disrupted the functioning of insect pests on cabbages therefore disrupting any insect activity that could have led to crop damage. [16] also postulated that garlic and onion acted as anti-feedants which reduced the ability of the insects or cutworms to feed on the transplanted cabbages. The 
results also are in line with the research carried out by [11] which showed that some chemicals produced by repellent plants such as onion or garlic that repelled insects.

\subsection{Cabbage diameter at physiological maturity}

Cabbage size in all the treatments did not significantly differ across all the treatments. This conforms to the research by [6] who indicated that canopy spread did not differ significantly. In another study with cabbagetomato intercrop, there was no significant difference in the size of the cabbage heads at maturity between the intercrop and the monocrops [5].

\subsection{Cabbage Yield in kg at physiological maturity.}

The weight of cabbages from the sole cabbage cropping system was reduced because the torn and mottled leaves were removed to remain with saleable products as a consequence of heavy pest attack. The sole cabbage plants that were infested early could not completely survive the attack and as a consequence produced lighter heads [6] and hence low mass. Similarly, foliar damage and yield loss was more in monocropped than intercropped plots [14].

\section{Conclusion And Recommendations}

The study has shown that garlic and onion when grown in intercrop repel insect pests in cabbages. It was noted that onion intercropped with cabbage between rows has a higher repellent effect than the intercrops where the garlic and the onion were planted within the cabbage rows. The planting pattern was also noted to be of significance in controlling insect pests. It clearly showed that garlic and onion are capable of repelling insect pests on leaf crops. Therefore, they are good companion crops in vegetable gardens. From the results of this research, it is recommended that smallholder farmers can practice intercropping with crop components that reduce pest infestation such as onion and garlic.

\section{References}

[1] Cabbage, Encyclopaedia Britannica, (Ultimate Reference Suite, Chicago, 2010).

[2] J. C. Norman, Developing Mixed Cropping Systems relating to the farmers environment. Proceedings of the first symposium on intercropping in semi-arid areas held at Mongoro. Tanzania. 1992 pp. 60-63.

[3] E. Asare-Bediako, A. A. Addo-Quaye, and A. Mohammed, A. (2010). Control of Diamond back Moth (Plutella xylostella) on Cabbage (Brassica oleracea var capitata) using Intercropping with Non-Host Crops. American Journal of Food Technology, 5(4), 2010, 269-274.

[4] G. De Lannoy Leafy Vegetables in Crop Production in Tropical Africa. Raemaekers, R.H (Ed)., (Directorate General for International Co-operation. Brussels, Belgium. 2001) 403-511.

[5] M. B. Mochiah, B. Banful, K. O.Fening, B. W. Amoabeng, K. Offei Bonsu, S. O. Ekyem, H. Braimah. M. Owusu-Akyaw, Botanicals for the management of insect pests in organic vegetable production. Journal of Entomology and Nematology. 3(8), 2011 pp 85-97

[6] P. K. Baidoo, M. B. Mochiah and K. Apusiga, Onion as a pest control intercrop in organic cabbage (Brassica oleracea)production system in Ghana, Sustainable Agricultural Research, Vol. 1 No. 1, 2012, 36-41.

[7] E. Dobson Integrated Vegetable Pest Management. Natural Resources Institute, (University of Greenwich, UK, 2002).

[8] B. Dube, M. M. Gova, P. R. Makaya and E. Mutimutema, Important vegetable pests and diseases in Zimbabwe, identification and control, (1999, AGRITEX, Harare, Zimbabwe).

[9] FAO, Convention on effects of pesticide residues in the soil, (2011, Geneva, Switzerland).

[10] S. Ahmed and G. Stoll, Bio pesticides, Biotechnology building on farmers knowledge, 1 ( London, McMillan education Ltd, 1996).

[11] J. Mc Callum, Genetic mapping of sulphur assimilation genes reveals a QTL for Onion bulb pungency. Theoretical Application Genetics. Volume 14. (2007, Geneva, Switzerland).

[12] G. Stoll, National Plant Protection in the tropics (1988, Magraf Publishers, Weikersheim, University of Greenwich, UK).

[13] F. T. Moran, Success in Vegetable and Fruit Production, Third Edition. (1992, Longman, Harare, Zimbabwe).

[14] E. K. P. O. Ogol and J. Makation, Potential of companion crops in managing the diamond backmoth in cabbage /kale cropping systems in Kenya. African Crop Science Proceedings, Vol 8, 2007, 1029-1033

[15] D. N. Enyiukwu, A. N. Awurum, C. C. Ononugu and J. A. Mwaneri, Significance of characterisation of secondary metabolites from extracts of higher plantsdisease management, International Journal of Advanced Agricultural Research Vol 2, 2014,pp 8-28

[16] J. T. Miller, Sustaining The Earth, Sixth Edition (2004, Thompson Learning Inc, California ).

\section{APPENDICES}

Appendix 1: Pest prevalence of insect pests on cabbage plants at physiological maturity

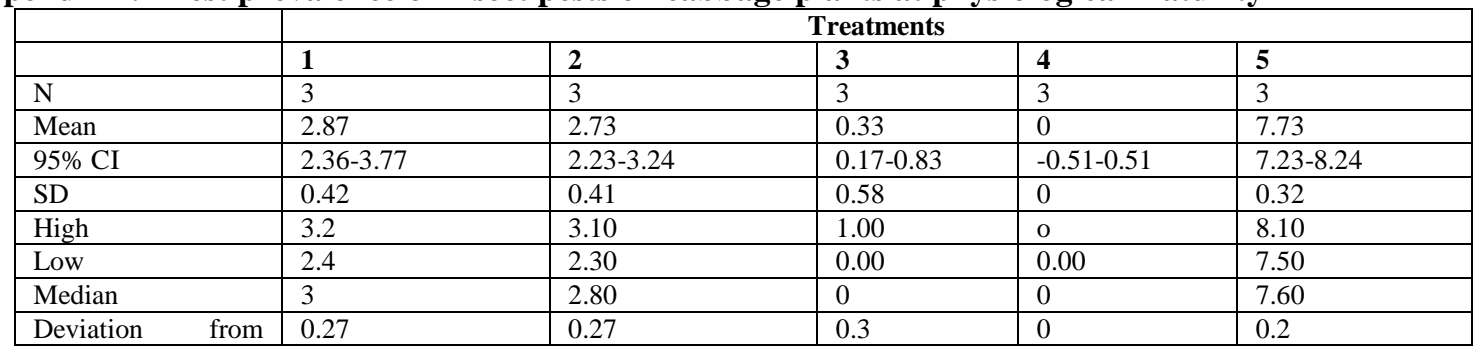


Onion (Allium cepa) and garlic (Allium sativum) as pest control intercrops in cabbage based

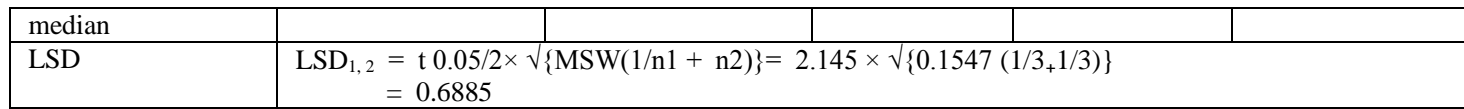

Appendix 2: Cabbage plants surviving at 3 WAP.

\begin{tabular}{|c|c|c|c|c|c|}
\hline 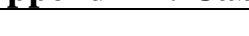 & \multicolumn{5}{|c|}{ Treatments } \\
\hline & 1 & 2 & 3 & 4 & 5 \\
\hline $\mathrm{N}$ & 3 & 3 & 3 & 3 & 3 \\
\hline Mean & 88.9 & 91.7 & 100 & 100 & 77.8 \\
\hline $95 \% \mathrm{CI}$ & $82.72-95.08$ & $85.52-97.88$ & $93.82-106.2$ & $93.82-106.2$ & $71.59-83.95$ \\
\hline SD & 4.85 & 0 & 0 & 0 & 9.58 \\
\hline High & 91.7 & 91.7 & 100 & 100 & 83.3 \\
\hline Low & 83.3 & 91.7 & 100 & 100 & 66.7 \\
\hline Median & 91.7 & 91.7 & 100 & 100 & 83.3 \\
\hline $\begin{array}{ll}\text { Deviation } & \text { from } \\
\text { median } & \end{array}$ & 2.80 & 0 & 0 & 0 & 9.58 \\
\hline LSD & \multicolumn{5}{|c|}{$\begin{aligned} \mathrm{L} \mathrm{S} \mathrm{D}= & \mathrm{t} 0.05 / 2 \times \mathrm{DFW} \sqrt{ }\{\mathrm{MSW}(1 / \mathrm{n} 1+1 / \mathrm{n} 2)\}=2.145 \times \sqrt{ }\{23.07(1 / 3+1 / 3)\} \\
& =8.412\end{aligned}$} \\
\hline
\end{tabular}

Appendix 3: Cabbage leaves that were damaged by insect pests at 6 WAP.

\begin{tabular}{|c|c|c|c|c|c|}
\hline & \multicolumn{5}{|c|}{ Treatments } \\
\hline & 1 & 2 & 3 & 4 & 5 \\
\hline Mean & 2.67 & 3.67 & 0 & 0 & 13 \\
\hline SD & 0.58 & 1.15 & 0 & 0 & 1.00 \\
\hline High & 3 & 5 & 0 & 0 & 14 \\
\hline Low & 2 & 3 & 0 & 0 & 12 \\
\hline $\begin{array}{l}\text { Deviation from } \\
\text { median }\end{array}$ & 0.33 & 0.67 & 0 & 0 & 0.67 \\
\hline LSD & \multicolumn{5}{|c|}{$\begin{aligned} \mathrm{L} \mathrm{S} \mathrm{D}= & \mathrm{t} 0.05 / 2 \times \mathrm{DFW} \sqrt{ }\{\mathrm{MSW}(1 / \mathrm{n} 1+1 / \mathrm{n} 2)\}=2.145 \times \sqrt{\{0.5333 \times(1 / 3+1 / 3)\}} \\
& =1.279\end{aligned}$} \\
\hline
\end{tabular}

Appendix 4: Cabbage head size $(\mathrm{cm})$ at physiological maturity

\begin{tabular}{|c|c|c|c|c|c|}
\hline . & \multicolumn{5}{|c|}{ Treatments } \\
\hline & 1 & 2 & 3 & 4 & 5 \\
\hline $\mathrm{N}$ & 3 & 3 & 3 & 3 & 3 \\
\hline Mean & 16.6 & 16.6 & 16.7 & 16.7 & 15.6 \\
\hline $95 \% \mathrm{CI}$ & $16.50-16.77$ & $16.50-16.77$ & $16.57-16.83$ & $16.60-16.87$ & $15.50-15.77$ \\
\hline SD & 5.77 & 0.12 & 1 & 0.12 & 0.12 \\
\hline High & 16.7 & 16.7 & 16.8 & 16.8 & 15.7 \\
\hline Low & 16.6 & 16.5 & 16.6 & 16.6 & 15.5 \\
\hline Median & 16.6 & 16.7 & 16.7 & 16.8 & 15.7 \\
\hline $\begin{array}{ll}\begin{array}{l}\text { Deviation } \\
\text { median }\end{array} & \text { from } \\
\end{array}$ & 3.33 & 6.67 & 6.67 & 6.67 & 6.67 \\
\hline LSD & $\mathrm{LSD}=\mathrm{t}$ & FW $\sqrt{\{M S W}$ & n2) $\}=2.145 \times$ & $(1 / 3+1 / 3)\}$ & \\
\hline
\end{tabular}

Appendix 5: Yield of cabbages in $\mathrm{kg}$ when harvested at physiological maturity.

\begin{tabular}{|c|c|c|c|c|c|}
\hline & \multicolumn{5}{|c|}{ Treatments } \\
\hline & 1 & 2 & 3 & 4 & 5 \\
\hline $\mathrm{N}$ & 3 & 3 & 3 & 3 & 3 \\
\hline Mean & 22.4 & 22.4 & 22.4 & 22.4 & 17.8 \\
\hline $95 \% \mathrm{CI}$ & $22.33-22.38$ & $22.33-22.38$ & $22.39-22.44$ & $22.42-22.47$ & $17.74-17.78$ \\
\hline SD & 5.77 & 1.12 & 3.06 & 1.53 & 2 \\
\hline High & 22.4 & 22.4 & 22.4 & 22.5 & 17.8 \\
\hline Low & 22.4 & 22.4 & 22.4 & 22.4 & 17.7 \\
\hline Median & 22.4 & 22.4 & 22.4 & 22.4 & 17.8 \\
\hline $\begin{array}{ll}\begin{array}{l}\text { Deviation } \\
\text { median }\end{array} & \text { from } \\
\end{array}$ & $3.3 \times 10-3$ & 6.67 & 2 & 1 & 1.33 \\
\hline LSD & $\begin{aligned} & \mathrm{LSD}= \mathrm{t} \\
&= \\
&=\end{aligned}$ & $\begin{array}{l}F W \sqrt{ }\{\mathrm{MSW} \\
\{3.466 \times(1 / 3+\end{array}$ & 12)\} & & \\
\hline
\end{tabular}

KEY

DFW (Degrees of freedom within means)

MSW (Mean Squares within Means) 